\title{
The Mode of Action of Aureomycin in the Guinea-pig
}

\author{
BY P. ROINE AND TERT'TU ETTALA \\ Department of Nutritional Chemistry, University of Helsinki, Finland \\ AUNE RAITIO AND U. VARTIOVAARA \\ Department of Microbiology, University of Helsinki, Finland
}

(Received 8 November I954)

In spite of its well-established position as a laboratory animal the guinea-pig's nutritional requirements are not yet thoroughly understood. It is well known, however, that some typical features make the guinea-pig different from other domestic or experimental animals. The best recognized of these is the need for ascorbic acid, which has made it the classical animal in research on vitamin C. Animal experimenters also know that the guinea-pig does not thrive on the purified diets proved adequate for many other laboratory animals, but needs additional factors whose properties are incompletely established. A further characteristic of its nutrition is the great significance of the intestinal fiora, still further complicating the clarification of its nutritional requirements.

The guinea-pig seems to be exceptional also in its response to antibiotics. We (Roine \& Ettala, 1952) were surprised to find in the course of investigations on intestinal synthesis in the guinea-pig that aureomycin (chlortetracycline) known to have growth-promoting action for many animals, caused rapid loss of weight and death when fed to guinea-pigs. Of other antibiotics tried (Roine, Ettala \& Raitio, 1953) oxytetracycline (terramycin) proved as 'toxic' as aureomycin, and streptomycin and succinylsulphathiazole also retarded normal growth. Penicillin, on the other hand, had no effect at the concentration used (50 $\mathrm{mg} / \mathrm{kg}$ diet), and chloramphenicol seemed to have a slight growth-promoting effect.

The literature shows that the harmful effect of aureomycin on guinea-pigs has been examined by Heilman (1948), Perry (1949), Finland, Collins, Gocke \& Wells (1949) and Renoux (195I), who report loss of weight and death after administration of this antibiotic. Similar observations were later made by Kiser (1952), Ambrus, Sideri, Johnson \& Harrisson (1952), Braude, Kon \& Porter (1953) and Ponzoni, Giberti \& Spampinato (1953). Toxic effects of penicillin (Ambrus et al. 1952; Miescher \& Böhm, r948; Gernez-Rieux \& Beerens, 1949; Stuart \& Slavin, I951 ; Rolle \& Mayer, 1953), streptomycin (Feldman \& Hinshaw, 1944) and oxytetracycline (Carrère \& Roux, I95I) also are known.

The present paper deals with the toxic effects of aureomycin on guinea-pigs and our attempts to explain it. Some of the results have already been published elsewhere (Roine \& Ettala, I952; Roine, Ettala \& Raitio r953; Roine, Raitio \& Vartiovaara, I953). 


\section{EXPERIMENTAL AND RESULTS}

\section{Management of animals and basal diet}

The guinea-pigs investigated were kept individually in wire-bottom cages at a temperature range of ${ }_{1} 8-22^{\circ}$. The percentage composition of the basal diet used in all experiments but one was: ground clover-timothy hay 20 , oatmeal 32 , rye meal 22.4 , casein 12 , margarine $3 \cdot 8$, salt mixture (1000 g sodium chloride, $1000 \mathrm{~g}$ calcium lactate, $30 \mathrm{~g}$ ferric citrate, $10 \mathrm{~g}$ manganese sulphate, $2 \mathrm{~g}$ copper sulphate, $0.2 \mathrm{~g}$ potassium iodide) $\mathrm{I} \cdot 6$, dried brewer's yeast 4 , wheat germ 4 and cod-liver oil $0 \cdot 2$. Ascorbic acid dissolved in sucrose solution, about $25 \mathrm{mg}$ daily, was fed to the animals individually by pipette. Both food and water were given $a d l i b$.

\section{Effects of aureomycin given by mouth}

\section{Experiments with basal diet}

Young guinea-pigs. In the first experiment $100 \mathrm{mg}$ aureomycin hydrochloride/kg were added to the diet and fed to nine guinea-pigs weighing $160-210 \mathrm{~g}$. All the animals began to lose weight on the 2nd day of the experiment and six died within to days. The remaining three survived and even gained weight after the initial loss, but within $5^{-6}$ weeks two of them died. In control animals receiving no aureomycin disturbances were absent.

Adult guinea-pigs. The aureomycin diet was then fed to six adult guinea-pigs of average weight $900 \mathrm{~g}$. All lost an average of $23 \mathrm{~g} /$ day from the ist day of feeding and died in 7-1 5 days.

\section{Experiments with purified diet}

In one experiment the purified guinea-pig diet of Roine, Booth, Elvehjem \& Hart (1949), containing sucrose, fat, casein, minerals, synthetic vitamins* and additional potassium and magnesium salts, was used instead of the basal diet described above. The results on this purified diet were similar to those on the more 'natural' basal diet: all four animals in the experiment died within 8 days.

\section{Effect of amount of aureomycin}

Table I gives the results of an experiment in which the effect of giving different amounts of aureomycin was studied. It can be seen that the fatal outcome was almost the same at the 100,50 or $25 \mathrm{mg} / \mathrm{kg}$ dosage levels. This is understandable because the animals ceased eating almost entirely after receiving the smallest amount of aureomycin. By measuring the quantity of food eaten it was estimated that as little as $0.1 \mathrm{mg}$ aureomycin was enough to induce severe illness in the animals. In general, the total amount of aureomycin consumed with food by each animal before death in different experiments was $\mathrm{I}-3 \mathrm{mg}$. It is noticeable from Table $\mathrm{I}$ that one of the

* We are indebted to F. Hoffmann-La Roche and Co., Basle (Switzerland) for some of the crystalline vitamins used in this investigation. 
animals survived and even gained weight after the initial loss. The same was observed from time to time in other animals in the course of the experiments. In all, about $5 \%$ of the animals tested survived after receiving an aureomycin diet.

\section{Effects of injected aureomycin}

Preliminary experiments. The first experiments showed that loss of weight and death also occurred when $\mathrm{I} \mathrm{mg} /$ day aureomycin was injected subcutaneously. However, smaller amounts given parenterally did not prove particularly harmful, as is shown in Table 2.

Table I. Effect of aureomycin given by mouth to guinea-pigs

$\begin{array}{cccccc}\begin{array}{c}\text { Aureomycin } \\ \text { in the diet } \\ (\mathrm{mg} / \mathrm{kg})\end{array} & \begin{array}{c}\text { No. of } \\ \text { animals }\end{array} & \begin{array}{c}\text { At beginning } \\ \text { of experiment }\end{array} & \begin{array}{c}\text { At } \\ \text { x week }\end{array} & \begin{array}{c}\text { At } \\ 2 \text { weeks }\end{array} & \begin{array}{c}\text { At } \\ \text { 3 weeks }\end{array} \\ 0 & 5 & 186 & 225 & 256 & 297(4) \\ 25 & 5 & 186 & 162 & -(0) & - \\ 50 & 4 & 197 & 163 & 218(\mathrm{I}) & 260(\mathrm{I}) \\ \text { roo } & 5 & 187 & 163(\mathrm{r}) & -(0) & -\end{array}$

Figures in parentheses indicate the number of survivors where deaths had occurred.

Table 2. Effect of aureomycin injected subcutaneously into guinea-pigs

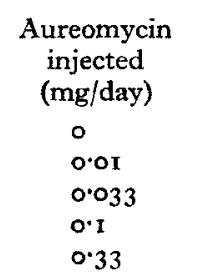

No. of
animals
2
4
4
4
3

\begin{tabular}{|c|c|c|c|}
\hline \multicolumn{4}{|c|}{ Mean weight (g) } \\
\hline $\begin{array}{l}\text { At beginning } \\
\text { of experiment }\end{array}$ & $\begin{array}{c}\text { At } \\
\text { I week }\end{array}$ & $\begin{array}{c}\text { At } \\
3 \text { weeks }\end{array}$ & $\begin{array}{c}\text { At } \\
6 \text { weeks }\end{array}$ \\
\hline 363 & 404 & 470 & 525 \\
\hline 388 & 407 & $45^{2}$ & 5 II \\
\hline 369 & 389 & 449 (3) & $5 \mathrm{I2}(3)$ \\
\hline 383 & 403 & $43^{8}$ & $497(3)$ \\
\hline 395 & 420 & 450 & 466 \\
\hline
\end{tabular}

Figures in parentheses indicate the number of survivors where deaths had occurred.

Table 3. Comparison of effects of aureomycin administered by mouth or subcutaneously to guinea-pigs in quantities of about $0.2 \mathrm{mg} /$ day*

\begin{tabular}{|c|c|c|c|c|c|}
\hline \multirow[b]{2}{*}{$\begin{array}{l}\text { Aureomycin } \\
\text { administered }\end{array}$} & \multirow[b]{2}{*}{$\begin{array}{l}\text { No. of } \\
\text { animals }\end{array}$} & \multicolumn{4}{|c|}{ Mean weight (g) } \\
\hline & & $\begin{array}{l}\text { At beginning } \\
\text { of experiment }\end{array}$ & $\begin{array}{c}\text { At } \\
\text { I week }\end{array}$ & $\begin{array}{c}\text { At } \\
3 \text { weeks }\end{array}$ & $\begin{array}{c}\text { At } \\
6 \text { weeks }\end{array}$ \\
\hline None & 5 & 177 & 225 & 299 & $418(4)$ \\
\hline By mouth & 5 & 173 & $-(0)$ & - & - \\
\hline Subcutaneously & 5 & 174 & 218 & 277 & 394 \\
\hline
\end{tabular}

Figures in parentheses indicate the number of survivors where deaths had occurred.

* See text, this page.

Comparison of the effects of subcutaneous injection and oral administration. An experiment was arranged with two groups of guinea-pigs. The food consumption of the animals in the group receiving aureomycin in the food was measured exactly every day and the corresponding amount of aureomycin was injected into the animals of the second group. The quantity was about $0.2 \mathrm{mg} /$ animal/day. The results given 
in Table 3 show that all five animals in the 'oral' group died in 7 days, whereas the animals in the 'subcutaneous' group were in good health and continued to grow at the normal rate during the following 5 weeks.

\section{Signs of 'aureomycin poisoning'}

Of the external manifestations of the disease it can be mentioned that the affected animal looks drowsy and keeps its eyes closed most of the time. A kind of ophthalmia can often be noticed and some animals have convulsions or turn round in circles. A clear sign of the disease is that the animal almost completely stops eating and to a large extent stops drinking. This behaviour makes the rapid loss of weight understandable. In some experiments the animals were force-fed by stomach tube with vitamins in quantities corresponding to the daily needs of the guinea-pig together with about $15 \mathrm{~g}$ sucrose and $5 \mathrm{~g}$ casein daily. These measures, however, did not keep the animals from falling ill when given aureomycin, neither did they in any way cure the disease already in progress.

Table 4. Weight of the caecum and $p H$ of the caecal contents in control guinea-pigs and in guinea-pigs given aureomycin by mouth

\begin{tabular}{|c|c|c|c|c|c|}
\hline \multicolumn{6}{|c|}{ (Mean values for groups of three animals) } \\
\hline & \multicolumn{2}{|c|}{ Weight of animal } & \multirow[b]{2}{*}{$\begin{array}{l}\text { Weight of } \\
\text { caecum }(\mathrm{g})\end{array}$} & \multicolumn{2}{|c|}{ Caecal contents } \\
\hline Group & $\begin{array}{l}\text { Initial } \\
(\mathrm{g})\end{array}$ & $\begin{array}{c}\text { Change } \\
\text { (g) }\end{array}$ & & $\begin{array}{l}\text { Dry matter } \\
(\%)\end{array}$ & $\mathrm{pH}$ \\
\hline \multicolumn{6}{|c|}{ After I day } \\
\hline Control & 170 & $-2 \cdot 7$ & $11 \cdot 2$ & $17 \cdot 4$ & $6 \cdot 6$ \\
\hline Aureomycin & I 82 & $-15 \cdot 7$ & $\mathrm{II} \cdot 8$ & $I 6 \cdot 6$ & $7 \cdot 0$ \\
\hline \multicolumn{6}{|c|}{ After 3 days } \\
\hline Control & 152 & $+2 \cdot 0$ & $12 \cdot 3$ & $15 \cdot 8$ & $6 \cdot 6$ \\
\hline Aureomycin & I 8 I & $-32 \cdot 7$ & $19 \cdot 3$ & $15^{\cdot 2}$ & $7 \cdot 3$ \\
\hline \multicolumn{6}{|c|}{ After 7 days } \\
\hline Control & 166 & $+x_{3} \cdot 3$ & $12 \cdot 4$ & $15 \cdot 8$ & $6 \cdot 3$ \\
\hline Aureomycin & I6I & $-42 \cdot 0$ & $x 9 \cdot 2$ & $15 \cdot 5$ & $7 \cdot 1$ \\
\hline
\end{tabular}

A distended belly was another sign of the disease. This was at least partly due to the caecum, much enlarged in the animals given aureomycin, as can be seen from the figures in Table 4 . These figures also show that the $\mathrm{pH}$ of the caecal contents was distinctly higher in the animals given aureomycin than in the controls. This may have been caused by a change in the population in the caecum. In the percentage of dry matter in the caecal contents no great differences were noticed.

The body temperature fell markedly after the administration of aureomycin. In one experiment the rectal temperature was found to fall from the original $37^{\circ}$ to $34^{\circ}$ during 8-1o days of experiment. Thyroxine injections given to stimulate the metabolism had no effect on the disease, nor could any improvement in it be brought about by $\mathrm{ACTH}$ injections.

The most characteristic manifestations in the inner organs were pale-grey focal necroses in the liver, usually $\mathrm{I}-\mathrm{I} .5 \mathrm{~mm}$ in diameter. Often the liver was also found to 
be darker in colour than normally. The spleen, on the other hand, was of a pale-pink colour and of decreased size. Red infarcts were often observed in the lungs.

Blood examination revealed no systematic differences between the control and aureomycin groups in the total number of erythrocytes or leucocytes. The differential leucocyte counts made by standard procedures* are given in Table 5 . It can be seen that the percentage of neutrophils increased during the aureomycin administration, whereas that of lymphocytes correspondingly decreased. The percentage of monocytes varied considerably from day to day; no definite monocytosis was observed. It may be mentioned that the effects of oxytetracycline and penicillin on the blood picture were similar to those of aureomycin. Chloramphenicol, on the other hand, had no obvious effects.

\begin{tabular}{|c|c|c|c|c|c|}
\hline \multicolumn{6}{|c|}{ to guinea-pigs for $1,3,5$ or 7 days } \\
\hline $\begin{array}{l}\text { Days } \\
\text { No. of animals }\end{array}$ & $\begin{array}{r}0 \\
15\end{array}$ & $\begin{array}{l}\text { I } \\
8\end{array}$ & $\begin{array}{r}3 \\
15\end{array}$ & $\begin{array}{l}5 \\
8\end{array}$ & $\begin{array}{l}7 \\
8\end{array}$ \\
\hline Neutrophils & $44: 5$ & $43 \cdot 3$ & $53 \cdot 5$ & $50 \cdot 7$ & $59 \cdot 0$ \\
\hline Eosinophils & $I \cdot I$ & 0.5 & 0.8 & $\pi 0$ & 0.5 \\
\hline Basophils & $I \cdot 9$ & $2 \cdot I$ & $I \cdot I$ & $2 \cdot 2$ & 0.8 \\
\hline Lymphocytes & $44 \cdot 5$ & $47^{\circ 2}$ & $33 \cdot 2$ & 40.0 & 30.5 \\
\hline Monocytes & $2 \cdot 7$ & $2 \cdot 9$ & $4 \cdot 9$ & 2.4 & $5 \cdot 2$ \\
\hline Kurlov cells & $5 \cdot 3$ & $4 \cdot 0$ & 6.5 & 3.7 & $4 \circ 0$ \\
\hline
\end{tabular}

\section{Bacteriological investigations}

From the finding that aureomycin was far more toxic to guinea-pigs orally than subcutaneously it was concluded that the action of the antibiotic must be primarily connected with the processes taking place in the digestive tract. Attention was therefore focused on the changes in the intestinal flora after oral administration of aureomycin.

The present knowledge of the normal intestinal flora of the guinea-pig is based mainly on the investigations of Crecelius \& Rettger (1943) and of Baker (1944). The findings differ somewhat, depending at least partly on the diet of the animals.

According to Crecelius \& Rettger (1943) the normal flora is relatively simple, consisting of a small number of bacterial types and of yeast-like micro-organisms. The predominating organism was found to be closely related to Lactobacillus acidophilus, and a second organism of particular interest was a large anaerobic Sarcina. In addition yeasts and common soil and air bacteria were present. According to Baker (1944) the intestinal population of the guinea-pig is more complicated, consisting of, for example, cocci, small rods and vibrios, giant amylococci, bacilli, spirochaetes, spirilla, Oscillospira, Fusobacterium, and Selenomonas.

Our own investigations were made on the caecal flora, simultaneously on the control and aureomycin groups. The animals were killed with chloroform, a $2.5 \mathrm{~g}$ sample of caecal contents was taken aseptically and dilutions $10^{-1}, 10^{-3}, 1^{-5}$ and $10^{-6}$ were made in the dilution medium of Huhtanen, Rogers \& Gall (1952). From these dilutions I ml. samples were inoculated into different media: an agar medium according to

* The authors wish to acknowledge with thanks the assistance of Miss Mai-Leena Ranta in carrying out the blood counts. 
Huhtanen et al. (1952), wort agar, EMB-agar and tomato agar (Kulp). Incubation was carried out at $37^{\circ}$ for $24^{-} 72 \mathrm{~h}$.

The agar cultures (Huhtanen et al. 1952) from the control animals contained an abundance of colonies resembling those of aerobic bacilli, and some yeast-like colonies. In the aureomycin group the number of colonies was smaller in general, but a striking feature was the occurrence of small, slimy colonies not observed in the control group. These colonies appeared when the animals had eaten the aureomycin diet for I day only and their number was markedly increased in the 3 -day samples.

On the wort agar many yeast and bacillus colonies grew in the control group, few in the aureomycin group. The tomato-agar tubes contained lens-shaped colonies, abundantly in the control group and many fewer in the aureomycin group. Growth on the EMB agar was in general relatively weak; Bacterium coli could seldom be found.

Table 6. Caecal micro-organisms in control guinea-pigs and in guinea-pigs kept I day on the aureomycin diet

\begin{tabular}{|c|c|c|}
\hline \multicolumn{3}{|c|}{ (10 $1 / 100 \mathrm{~g}$ caecal contents) } \\
\hline Organism & Control animals & aureomycin \\
\hline Oscillospira & I5.I & 0.02 \\
\hline Fusobacterium & $17 \cdot 1$ & 0.05 \\
\hline Borrelia & $10 \cdot 8$ & 0 \\
\hline Streptococcus & $6 \cdot 4$ & ro.o \\
\hline Yeast & $4 \cdot 1$ & $2 \cdot 0$ \\
\hline Sarcina & $1 \cdot 9$ & I5.0 \\
\hline Trichomonas & 0.0 & I.0 \\
\hline \multicolumn{3}{|c|}{ Gram-positive rods: } \\
\hline Lactobacillus & $22 \cdot 3$ & $3 \cdot 5$ \\
\hline Bacillus & 17.0 & $13 \cdot 0$ \\
\hline Listeria & $x \cdot 8$ & II*4 \\
\hline
\end{tabular}

The number of each type of colony was estimated roughly and agar-slant or stab cultures were prepared from all the colonies showing differing appearances. A determinative study of the cultures showed that many of the organisms isolated were identical, the total flora thus consisting of relatively few species. The following genera were identified: Bacillus, Lactobacillus, Streptococcus, Sarcina, Proteus and Listeria. Yeast cells were also present.

After the main organisms of the intestinal flora had been identified and their morphological characteristics determined, their numbers in the caecal contents were counted by direct microscopy. For this purpose $0.05 \mathrm{ml}$. of the dilution $10^{-1}$ was spread over $5 \mathrm{~cm}^{2}$ of an object slide and Gram-stained. The numbers of each morphologically different organism were then counted from twenty arbitrary fields, in three separate preparations for each animal. In addition to the species listed above, cells of Fusobacterium, Oscillospira (cf. Baker, I944) and Borrelia were also found by this method. The average numbers of the different organisms in the control animals and in the animals kept I day on the aureomycin diet are given in Table 6. The figures are only approximate, especially since it is very difficult to distinguish between the different types of Gram-positive rods by this method, but they give a general picture of the situation. It can be seen that aureomycin almost completely eliminated the 
cells of Oscillospira, Fusobacterium and Borrelia and greatly reduced the number of lactobacilli. Sarcina and Listeria cells, on the other hand, considerably increased in number.

A similar counting of the organisms was made for the caecums of animals kept on the control or aureomycin diets for 3 days. The most significant difference between the 3-day and I-day counts was the abundance of Proteus cells after 3 days in the aureomycin group. It is interesting to note that Renoux (I95I) isolated Proteus mirabilis from guinea-pigs on an aureomycin diet and suggested that the toxicity of aureomycin for guinea-pigs is due to the growth of this organism. From our experience, however, the harmful effects are evident long before Proteus appears in abundance.

It is difficult to believe that a decrease in number of any bacterial species and a corresponding decline in its synthetic activities could harm the animal with the rapidity observed in our experiments. In explaining the mechanism of aureomycin poisoning we had, therefore, to concentrate on the organisms whose numbers were found to increase as a result of aureomycin feeding. Listeria became a natural object of suspicion. It is well known (cf. Murray, I953) that Listeria monocytogenes occurs as a parasite in a great number of wild and domestic animals and birds, including the guinea-pig. Many cases of Listeria infection in sheep, cattle, pigs, chickens, horses and minks have been reported (Westermarck, 1946; Stenberg, 1953) in Finland. The signs in our experiments described above are all typical of Listeria infection, although the disease has somewhat different characteristics in different animals (cf. Murray, 1953).

Isolation of Listeria from our aureomycin-fed guinea-pigs proved rather difficult since other organisms, especially bacilli, tend to cover the medium more rapidly. The isolated organism had the following characteristics.

Colonies on the agar medium of Huhtanen et al. (1952) were $1.5-2.5 \mathrm{~mm}$ in diameter, flat, smooth, viscid in consistency, transparent by transmitted and milkwhite by reflected light. They consisted of small rods originally $0.5 \times \mathrm{I}-2 \mu$, in pure cultures $0.5 \times 2-4 \mu$. They occurred often in V-shaped pairs, had rounded ends, did not form spores or capsules, were not acid-fast and were Gram-positive (often Gramvariable when older). No liquefaction was obtained in gelatine stabs, in which the growth was granular and surrounded the needle track. The organisms showed $\beta$-haemolysis on human blood agar; they produced acid but no gas from glucose; acid was formed more slowly from maltose and lactose and very slowly from sucrose. Arabinose and mannitol were not fermented and hydrogen sulphide was not formed. Cultures were methyl-red positive, Voges-Proskauer negative and had a typical sour unpleasant smell.

When an agar culture of the isolated organism, suspended in physiological saline, was injected intraperitoneally into healthy guinea-pigs signs similar to those described above developed and the animals died within a week. The spleens, however, which in the aureomycin-fed animals had shrunk and were pale pink in colour, were in these large and dark purple, an observation made earlier on rabbits injected with Listeria cultures (cf. Topley \& Wilson, 1936). 
According to Murray (1953) and Gerard \& Murray (195I) the most striking effect of $L$. monocytogenes is the production of mononucleosis with a great increase in the monocyte count. As stated above, no monocytosis could be found in our aureomycinfed guinea-pigs. Although we have not investigated further this important detail, the failure to find monocytosis in our animals points to the possibility that our organism is not identical with the L. monocytogenes generally described in the literature. Until extensive investigations have been made with other host species we cannot know with certainty whether our organism is $L$. monocytogenes proper or should be regarded as a hitherto unknown strain of the species or perhaps as a separate species of the genus.

\section{Prevention or cure of the 'poisoning'}

In vitro testing of the activity of different antibiotics on the isolated cultures of Listeria showed that at the same weight level penicillin was, as could be expected, much more effective against this organism than aureomycin. Chloramphenicol, too, was at first found to be somewhat more effective than aureomycin, but in the later experiments the effects of these two antibiotics were found to be almost equal. This finding suggested that the aureomycin-induced condition could be cured or prevented by penicillin and possibly even by chloramphenicol. Experiments were therefore arranged in which penicillin or chloramphenicol was given before, simultaneously with, or after the beginning of the aureomycin feeding.

Five guinea-pigs were fed on the diet containing aureomycin (100 mg/kg) for 3-5 days, in which time the animals contracted the typical illness and their weights fell abruptly from the Ist day of feeding. Subsequently, two animals were given daily by mouth $3^{-5} \mathrm{mg}$ penicillin and three animals $14^{-20} \mathrm{mg}$ chloramphenicol. The animals receiving chloramphenicol ceased losing weight in the course of a few days, began to eat again and to gain weight. One of the animals receiving penicillin recovered too; the second one improved only temporarily and died later. It is to be noted that all the animals were kept throughout on the diet containing aureomycin; the administration of penicillin or chloramphenicol thus overcame the toxic effects of aureomycin.

In other experiments penicillin or chloramphenicol was given before the aureomycin feeding. Ten animals were fed on a diet containing penicillin $(100 \mathrm{mg} / \mathrm{kg}$ ) and eight animals on a diet containing chloramphenicol $\left(300 \mathrm{mg} / \mathrm{kg}\right.$ ) for $5^{-8}$ days, after which they were transferred to the aureomycin diet. Three of the ten that had received penicillin fell ill after the beginning of the aureomycin feeding and died; seven animals survived, though some of them first seemed to be affected by the aureomycin feeding. Of the eight animals that had received chloramphenicol, five died on aureomycin and three survived. Feeding on the aureomycin diet was always continued for at least 2 weeks to be sure that the survivors were not affected by it.

In a third group of experiments the animals were fed on diets containing a combination of aureomycin $(100 \mathrm{mg} / \mathrm{kg})$ and penicillin $(300 \mathrm{mg} / \mathrm{kg})$ or chloramphenicol $(300 \mathrm{mg} / \mathrm{kg})$. Most of the animals on these diets died but in two the disease was prevented. 
It was thus frequently possible to cure or prevent the aureomycin-induced disease by administering penicillin or chloramphenicol. The best results were obtained with penicillin, but the dosage presented rather a problem, for at higher concentrations this antibiotic is itself toxic for the guinea-pig. In general, it is evident that positive results in this kind of experiment with different antibiotics in combination can never be guaranteed because of the risk of too drastic changes in the normal intestinal flora. The experiments performed do, however, support our theory as to the bacterial nature of the 'toxicity' of aureomycin for guinea-pigs.

\section{DISCUSSION}

It is well known that antibiotics stimulate the growth of many farm and laboratory animals. Various theories are held as to the modes of their action. Though it is probable that there are several different effects, the theory derived mainly from the experiments of Coates and co-workers (Coates, Dickinson, Harrison, Kon, Cummins \& Cuthbertson 1951; Coates, Dickinson, Harrison, Kon, Porter, Cummins \& Cuthbertson, 195I) deserves special attention. According to these workers the growth of chicks was stimulated with penicillin only when the chicks were housed in a laboratory used for poultry for some years, no stimulation being observed in chicks kept in new poultry quarters. These findings, which have been confirmed by others, led to the theory that animals are normally 'infected', i.e. their guts harbour harmful organisms or viruses that reduce their growth potential. By eliminating these factors the antibiotics make possible optimal growth.

Our own findings described in the preceding pages, although concerned with a phenomenon opposite to growth promotion, agree well with the 'infection' theory. They indicate that the guinea-pig is normally infected with Listeria organisms. These organisms play a subordinate part only and cause no apparent impairment. Aureomycin, however, by suppressing other organisms, promotes the dominance of the Listeria flora, which generally leads to the death of the animal. If the Listeria flora can be destroyed by other antibiotics, e.g. penicillin, the harmful effects of aureomycin disappear. Sometimes Listeria evidently becomes predominant even in the absence of aureomycin, since a local dealer in guinea-pigs has reported cases of natural infection with signs similar to those found in our aureomycin-fed animals. By contrast, judging by the fact that a few animals survived in spite of aureomycin feeding, there seem to be individual animals that are not infected, at least not sufficiently for the disease to be fatal. It is interesting to note that according to recent work by Rolle \& Mayer (1953) the toxicity of penicillin to the guinea-pig is due to the fact that this antibiotic suppresses the indispensable symbiotic flora of the animal and causes a fatal dominance of Bact. coli.

Our results give an example also of the risks in some circumstances of using new antibiotic drugs. Harmless to the host animal or man as they may be, they can bring about profound and sometimes deleterious changes in the normal intestinal flora. These can lead, as is well known, to vitamin deficiencies, diarrhoea and other intestinal disorders, and at the worst to consequences as injurious as those observed in our guinea-pigs. 


\section{SUMMARY}

I. Aureomycin was found to be fatal to guinea-pigs when fed at levels producing growth promotion in many other animals. As little as a total of $0.1 \mathrm{mg}$ of this antibiotic caused the test animals to stop eating and drinking almost entirely and most of them to die within $1-2$ weeks. Daily subcutaneous injections of $0 \cdot 1-0.3 \mathrm{mg}$ aureomycin had almost no effect, but in large doses even parenteral administration proved harmful.

2. The signs of the 'poisoning' varied to some extent with individual animals, but usually included a kind of ophthalmia, a distended belly, mainly due to a very enlarged caecum, a fall in the body temperature, focal necroses in the liver, a diminished palepink spleen and red infarcts in the lungs. The count of neutrophils in the blood increased and the lymphocyte count decreased. No distinct regular increase in monocytes could be established.

3. Bacteriological investigations showed distinct differences between the caecal flora of control animals and of those receiving aureomycin. A striking feature in the aureomycin group was the abundance of an organism belonging to the genus Listeria. A direct microscopical examination of the caecal contents showed that feeding with aureomycin had considerably increased the numbers of Listeria and Sarcina, greatly reduced the lactobacilli and almost completely eliminated cells of Oscillospira, Fusobacterium and Borellia. It seems logical to assume that the toxic effects of aureomycin are due to the increase of the Listeria flora, expecially as Listeria monocytogenes is known to occur as a parasite in a great number of wild and domestic animals, causing infections with signs mostly similar to those found in the aureomycin-fed guinea-pigs.

4. In many instances the toxic effects of aureomycin were prevented by previous (or combined) administration of penicillin, and even animals already diseased were cured with this antibiotic. Chloramphenicol also, in a few instances produced positive results.

5. The results obtained support the 'infection' theory advanced to explain growth promotion by antibiotics. Listeria seems to be a regular parasite of the guinea-pig, but it evidently has, under normal conditions, only a subordinate position with no apparent harmful effects. By suppressing other intestinal organisms, aureomycin may promote the Listeria population to predominance, generally leading to the death of the animal.

\section{REFERENCES}

Ambrus, C. M., Sideri, C. N., Johnson, G. C. \& Harrisson, J. W. E. (1952). Antibiotics and Chemotherapy, 2, $52 \mathrm{I}$.

Baker, F. (1944). Ann. appl. Biol. 3r, I2 I.

Braude, R., Kon, S. K. \& Porter, J. W. G. (1953). Nutr. Abstr. Rev. 23, 473.

Carrère, L. \& Roux, J. (I95I). Ann. Inst. Pasteur, 81, 352.

Coates, M. E., Dickinson, C. D., Harrison, G. F., Kon, S. K., Cummins, S. H. \& Cuthbertson, W. F. J. (195x). Nature, Lond., 168, 332.

Coates, M. E., Dickinson, C. D., Harrison, G. F., Kon, S. K., Porter, J. W. G., Cummins, S. H. \& Cuthbertson, W. F. J. (195 I). F. Sci. Fd Agric. 3, 43.

Crecelius, H. G. \& Rettger, L. F. (1943). F. Bact. 46, 1.

Feldman, W. H. \& Hinshaw, H. C. (1944). Proc. Mayo Clin. 19, 59r.

Finland, M., Collins, H. S., Gocke, T. M. \& Wells, E. B. (1949). Ann. intern. Med. 3I, 39.

Gerard, K. F. \& Murray, E. G. D. (I95 I). Amer. F. Sci. 221, 343.

Gernez-Rieux, C. \& Beerens, H. (1949). Ann. Inst. Pasteur Lille, 2, 100. 
Heilman, F. R. (1948). Proc. Mayo Clin. 23, 569.

Huhtanen, C. N., Rogers, M. R. \& Gall, L. S. (1952). \%. Bact. 64, I7.

Kiser, J. S. (1952). Personal communication.

Miescher, G. \& Böhm, G. (1948). Schweiz. med. Wschr. 77, 82 1.

Murray, E. G. D. (1953). Trans. roy. Soc. Can. $3^{\text {rd }}$ ser., 47, 15.

Perry, T. L. (1949). Proc. Soc. exp. Biol., N.Y., 72, 45.

Ponzoni, R., Giberti, A. \& Spampinato, V. (1953). Boll. Ist, sieroter. Milano, 32, 239 (quoted in Nutr. Abstr. Rev. (1954), 24, 75).

Renoux, G. (1951). Ann. Inst. Pasteur, 81, 54I.

Roine, P., Booth, A. N., Elvehjem, C. A. \& Hart, E. B. (1949). Proc. Soc. exp. Biol., N. Y., 71, 90.

Roine, P. \& Ettala, T. (1952). Nature, Lond, 169, 1014.

Roine, P., Ettala, T. \& Raitio, A. (1953). Acta chem. fenn. B, 26, 17.

Roine, P., Raitio, A. \& Vartiovaara, U. (1953). Nature, Lond,, 172, 767.

Rolle, M. \& Mayer, H. (1953). Arch. Hyg., Berl., 137, 596.

Stenberg, H. (1953). Finsk VetTidskr. 59, 394.

Stuart, P. \& Slavin, G. (1951). Nature, Lond., 167, 319.

Topley, W. W. C. \& Wilson, G. S. (1936). The Principles of Bacteriology and Immunity, and ed. London: E. Arnold and Co.

Westermarck, H. (1946). Finsk VetTidskr. 52, 227.

\title{
Antibiotics and Endocrine Stimulants as Promoters of Growth in Fattening Pigs
}

\author{
By R. BRAUDE* \\ National Institute for Research in Dairying, University of Reading \\ R. C. CAMPBELL† \\ Agricultural Research Council's Unit of Reproductive Physiology \\ and Biochemistry, University of Cambridge \\ I. A. M. LUCAS \\ Rowett Research Institute, Bucksburn, Aberdeenshire \\ J. R. LUSCOMBE \\ Harper Adams Agricultural College, Newport, Shropshire \\ K. L. ROBINSON \\ The Queen's University of Belfast \\ AND J. H. TAYLOR \\ Agricultural Research Council's Field Station, Compton
}

(Received 25 November 1954

Barber, Braude \& Mitchell (I953) reported that the growth-promoting effect associated with the feeding of an antibiotic to pigs was enhanced when it was fed together with small amounts of L-thyroxine and stilboestrol. In order to investigate these findings further, experiments were arranged at the following four centres: the 